Review

\title{
Livestock Under Climate Change: A Systematic Review of Impacts and Adaptation
}

\author{
Jacquelyn F. Escarcha *(D), Jonatan A. Lassa ${ }^{(1)}$ and Kerstin K. Zander \\ Northern Institute, Charles Darwin University, Darwin, NT 0909, Australia; jonatan.lassa@cdu.edu.au (J.A.L.); \\ Kerstin.Zander@cdu.edu.au (K.K.Z.) \\ * Correspondence: Jacquelyn.Escarcha@cdu.edu.au; Tel.: +61-8-8946-6659
}

Received: 24 May 2018; Accepted: 19 June 2018; Published: 21 June 2018

check for updates

\begin{abstract}
We conducted a systematic literature review to document the scientific knowledge about climate change impacts and adaptation in livestock systems, and to identify research gaps. The analysis was built from the premise that livestock offers substantial opportunities for food security and sustainable development if adaptation to climate change is appropriated. In examining 126 suitable peer-reviewed publications we discovered five research gaps: (1) a lack of research in Asia and South America; (2) a lack of mutual investigation and linkages between impacts and adaptation; (3) a lack of emphasis on mixed crop-livestock systems; (4) a lack of emphasis on monogastric livestock; and (5) an underrepresentation of quantitative methods including yield impact models. The findings suggest that the research on climate change impacts and adaptation in livestock systems needs to move beyond certain geographical contexts and consider key vulnerability priorities, particularly from developing countries. It is pivotal that research begins to jointly look at climate change impacts and the livestock keepers' adaptation to draw out policy implications and to effectively target support for impact-specific adaptation options. Only if such evidence is established, adaptation will be appropriated accordingly to the needs of the livestock sector, and provision for the growing demand of animal-based products will be secured.
\end{abstract}

Keywords: agriculture systems; livestock production; climate change risks; impact assessments; sustainable adaptation

\section{Introduction}

Global livestock production is now under immense pressure. The increasing demand for livestock products has been largely driven by population growth, urbanization, increase in incomes, and shifts in diet [1,2]. Livestock systems operate under a wide range of environmental conditions, causing production to be increasingly affected by climate change. A quarter of the global economic impact caused by climate-related extremes was absorbed by the agriculture sector, wherein livestock, next to the crop subsector, faces most of the total damage and loss [3]. The livestock sector has recently had the lowest annual increase in meat production (1 percent in 2016; [4]). The future of the livestock sector will be increasingly challenging with the projected scarcity of resources crucial for production, particularly land and water, under climate change [5]. Climate change leads to reductions in livestock productivity by directly depressing animals' adaptive response mechanisms, altering the spread and prevalence of diseases [6], and causing heat stress and related welfare issues [7]; and indirectly by compromising the availability of feed crops and quality of forages [8]. Thus, generating research evidence of climate change impacts and adaptation on livestock will have important implications for the development of the sector and the people depending on it.

Livestock production employs 1.3 billion people and sustains livelihoods of about 900 million poor people worldwide [9]. Livestock and animal source food provide $14 \%$ of the total calories and 33\% 
of the proteins in the world population's diets [4]. Further, livestock has the potential to strengthen resilience to climate change, as it tends to be more resilient than crop-based systems [10]. However, to enhance livestock resilience to climate change, a better understanding is needed of the way the sector is affected [11]. Effective policy and practice requires sector-specific data about the nature and magnitude of impacts triggered by climate change $[12,13]$. As the extent to which climate change impacts vary across different livestock systems [14,15], understanding these differences is critical to the formulation of policy and practices [16]. Alignment of knowledge on climate change impacts and adaptation across different scales is also important to identify common concerns that can encourage collaboration among different production systems, and areas which climate change is likely to impact negatively [17]. Likewise, the unidentified gaps in research relating to climate change impacts and adaptation in livestock limits the understanding, and weakens the ability, of the sector to deal with future climate change impacts and to monitor adaptation progress over time.

As the livestock sector is very dynamic, there have been relatively few studies on climate change impacts on livestock, as compared to crops [18], and the available evidence is still fragmented [19]. Data on the damage and losses caused by climate change is not systematically collected or reported worldwide [3]. In addition, collecting and synthesizing livestock data is always a challenge because of heterogeneous production systems, varied agroecological zones, and, in most cases, different production objectives $[20,21]$. There are also a variety of practices across production systems according to cultural, socio-economic, and institutional conditions [22,23]. Ultimately, the importance of livestock to a country's development agendas depends on the multiple socio-economic values, and the cultural benefits it provides [24,25].

A few reviews have documented climate change impacts on livestock productivity $[17,26,27]$ and on peoples' livelihoods in developing regions $[15,23,28]$. Previous research has also investigated climate change impacts on livestock, including through higher frequencies of weather extremes, such as droughts [29], floods [30], and heat waves [7], as well as variations in rainfall and temperature [31]. However, no global systematic reviews have been undertaken on how the livestock sector is affected by and adapts to climate change.

Here we systematically document the available knowledge on climate change impacts and adaptation in the livestock sector. Our aims are to (1) assess the main climate change impacts on the livestock sector; (2) determine which areas of livestock production are affected the most; (3) synthesize adaptation responses in different production systems; and (4) reveal research gaps regarding impacts and adaptations relevant to different production systems. Specifically, two indicative questions were posed to guide the review process: (1) What is the current documented evidence of climate change effects on different livestock production systems; and (2) how do these climate change impacts trigger responses or links to adaptation across the different systems?

\section{Materials and Methods}

We conducted a systematic review of which the benefits are transparency, rigor, and replicability [32], following the Preferred Reporting Items for Systematic Reviews and Meta-Analyses (PRISMA) guidelines [33], which have also been used in previous climate science related systematic reviews [34,35].

\subsection{Search Strategy and Selection of Literatures}

We carried out an electronic literature search to capture relevant peer-reviewed articles published in the English language only, with no imposed limits on the year of publication, study design, or geographical coverage. We aimed to limit the selection of literature to studies that explicitly cover climate change and its impact on livestock, and further, showed links to adaptation in the livestock sector. As "climate change" can manifest itself in various ways (e.g., change, variability, and extremes), and "livestock" often excludes "poultry", different keyword combinations were used to capture the fullness of the topic. Further, as the concepts of "impact" and "adaptation" are strongly intertwined, and also encompass "risk", "resilience", and "vulnerability", a supplemental manual search was 
carried out [36]. The lead author independently conducted the database searches between 1 September and 15 October 2017. The search was run in Scopus and Web of Science, and included titles, abstracts, and keywords. The search strategy was specific to each of the two databases (see Figure 1).

The key search terms used in combinations were: "climate change" (weather, variability), "livestock" (poultry*ruminants), "impact" (heat stress; feeds; pasture; production; reproduction; health; vector-diseases), and "adaptation" (strategies; vulnerability; risks; resilience). The search resulted in a total of 427 articles (excluding duplicates). Inclusion and exclusion criterion were applied on these 427 articles and we finally retained 126 articles, which were reviewed in full detail and analyzed further.

\begin{tabular}{|c|c|c|c|c|c|}
\hline \multicolumn{2}{|c|}{ Literature search } & \multicolumn{3}{|c|}{$\underline{\text { Study selection }}$} & \\
\hline \multicolumn{2}{|c|}{ 1. Electronic databases } & \multirow{2}{*}{\multicolumn{3}{|c|}{$\begin{array}{c}1^{\text {st }} \text { Screening: } \\
\text { Based on title, abstracts, and } \\
\text { document type }\end{array}$}} & \multirow{9}{*}{$\begin{array}{l}\quad \text { Selection criteria } \\
\text { Inclusion: studies that address climate } \\
\text { change effects or climate-related } \\
\text { impacts and adaptation in livestock; } \\
\text { peer-reviewed materials; published in } \\
\text { English language } \\
\text { Exclusion: studies that do not focus on } \\
\text { livestock-climate change impacts- and } \\
\text { adaptation; unpublished grey literatures } \\
\text { (conference papers, editorial materials); } \\
\text { written in other languages other than } \\
\text { English }\end{array}$} \\
\hline \multirow{3}{*}{$\begin{array}{l}\text { Scopus } \\
\text { (Article title, } \\
\text { Abstract, } \\
\text { Keywords) }\end{array}$} & \multirow{3}{*}{ 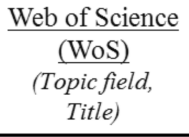 } & & & & \\
\hline & & & & & \\
\hline & & $\underline{\text { Scopus }}$ & (wos) & Manual & \\
\hline Total hits: 309 & Total hits 155 & & 10ta1. JJ & 10 tail. 15 & \\
\hline IVtai ints. Joy & Iotal mils. 155 & & & & \\
\hline \multicolumn{2}{|c|}{ 2. Manual searches } & \multicolumn{3}{|c|}{ Total articles selected: 148} & \\
\hline \multicolumn{2}{|c|}{ Total hand search: 15} & \multicolumn{3}{|c|}{$\downarrow$} & \\
\hline \multirow{2}{*}{\multicolumn{2}{|c|}{$\begin{array}{c}52 \text { Duplicates removed } \\
\downarrow\end{array}$}} & & $\frac{\text { Screenin }}{\text { ed on full- }}$ & & \\
\hline & & & & & \\
\hline \multicolumn{2}{|c|}{$\begin{array}{c}\text { Total retrieved articles: } \\
\qquad 427\end{array}$} & \multicolumn{3}{|c|}{$\begin{array}{l}\text { Total included for full-text review: } \\
\qquad 126\end{array}$} & Final articles for data extraction \\
\hline
\end{tabular}

Figure 1. Search and selection process of the documents for review.

\subsection{Data Management, Coding, and Analysis}

We imported the final 126 articles from Endnote into Nvivo11 for further synthesis, coding, and analysis. The use of this software helped to reduce human error in data coding and analyzing the content using multiple factors in the literatures for review [37]. Bibliographic information was automatically classified once imported. A list of data categories was developed beforehand to ensure consistency of data extracted from individual articles (see Supplementary Materials S1). Based on the pre-determined categories, data were identified and coded as nodes and cases for further analysis. Nodes included the key concepts for content analysis, while cases were coded such as to include information on the background of the publications selected. Data were coded accordingly, as reported from the 126 included documents. To identify the key literature trends, the bibliographic information and background of included documents were transformed first into quantitative measures [38].

We used content analysis to synthesize the extracted data, infer contextual meanings, and further define the scope of the review [39]. Data summaries were created into tabulations of frequency counts and percentages. Qualitative evidences were drawn on the nodes that were initially developed: "exposure", "impacts", "adaptation", and "implications and knowledge gaps". Data content within each of these nodes were classified into sub-categories. Common findings were collated through interactive visualizations.

\section{Results}

\subsection{Number and Type of Publications}

The number of peer-reviewed papers on climate change impacts and adaptation in the livestock sector has increased rapidly since 2000 (see Figure 2a). The very few publications (seven articles) before 2000 were excluded because they were not associated with livestock. The classification based on 
the first author's affiliations demonstrated that the considered publications were written by authors from research and higher education sectors (50\%), governmental (33\%), non-governmental (11\%), and inter-governmental organizations (4\%). A few were published by private environmental consulting firms $(2 \%)$ (see Figure $2 b$ ).

Though most publications were journal articles $(74 \%)$, there were some reviews $(16 \%)$, and book chapters (10\%) (see Figure $2 \mathrm{c}$ ). The publications were methodologically conducted either as conceptual $(52 \%)$ or empirical $(48 \%)$ studies. Results from this research were derived from secondary data through conceptual synthesis, $43 \%$ on primary investigations using case/cross-sectional studies and $6 \%$ on experimental/statistical modelling methods. Publications that used secondary data were mostly qualitative in nature containing reviews and conceptual articles. These mainly covered generic assessments and descriptions of likely climate change impacts and adaptation challenges facing livestock. There were few publications relating to quantification of climate change impacts and adaptation in livestock systems (6\%).

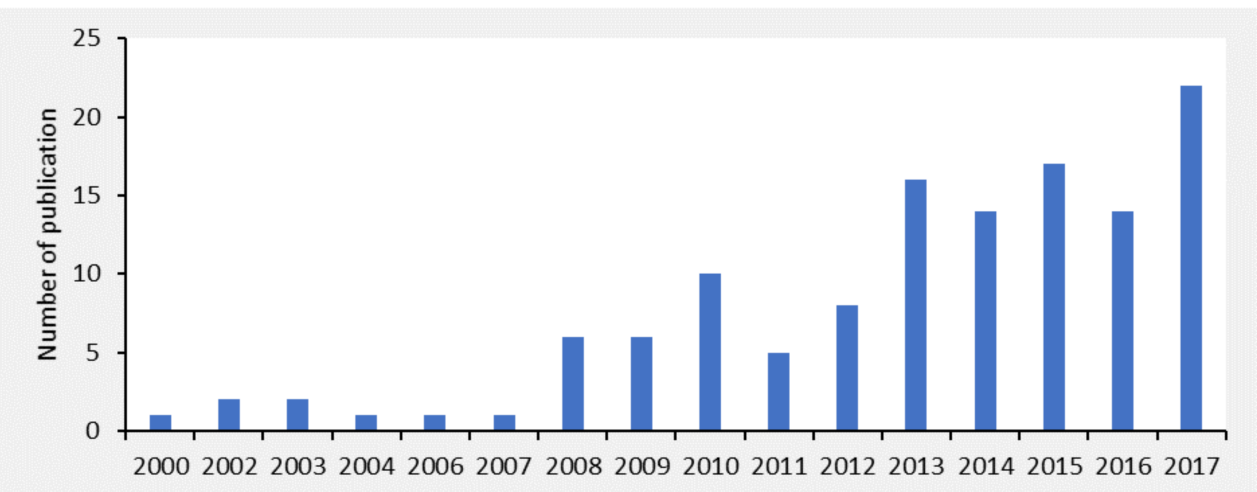

(a)

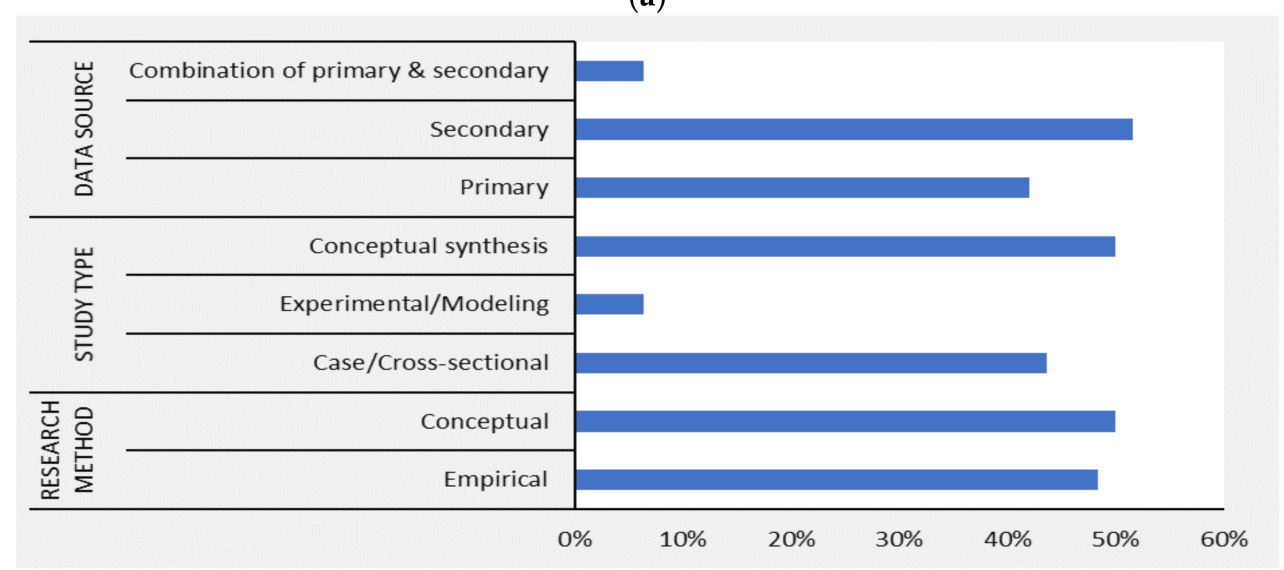

(b)

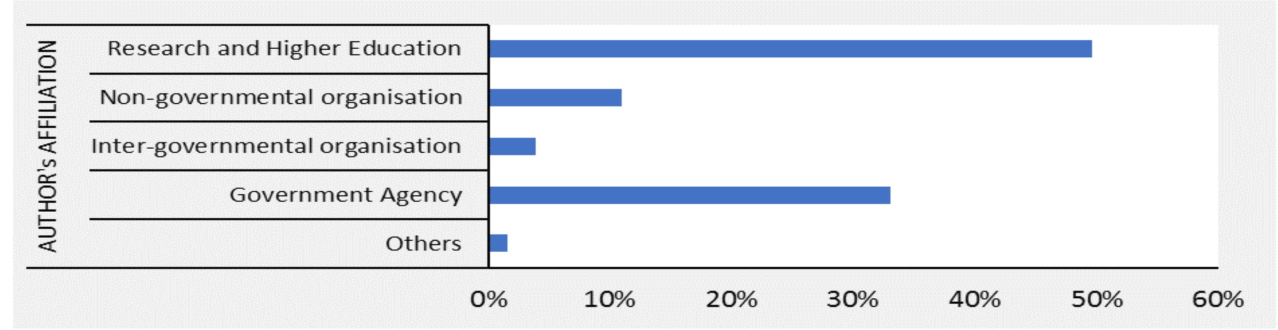

(c)

Figure 2. Publications reviewed grouped by (a) number of publication by year; (b) methodological background; and (c) classification of first authors by affiliation; $N=126$. 


\subsection{Geographical Concentration}

Though most publications were country-specific (57\%), some were global (23\%), and some regional (20\%). The split between developing (45\%) and developed (43\%) countries or regions was nearly equal, with the remaining $12 \%$ having global coverage. The United States and Australia (42\%) dominated the studies from the developed world followed by India, China, and the United Kingdom (see Figure 3). Most publications from the developing world were from Africa (56\%), and these were largely from Ethiopia and Kenya (45\%). Only a few of the publications from developing countries were from Asia (23\%) or South America (4\%).

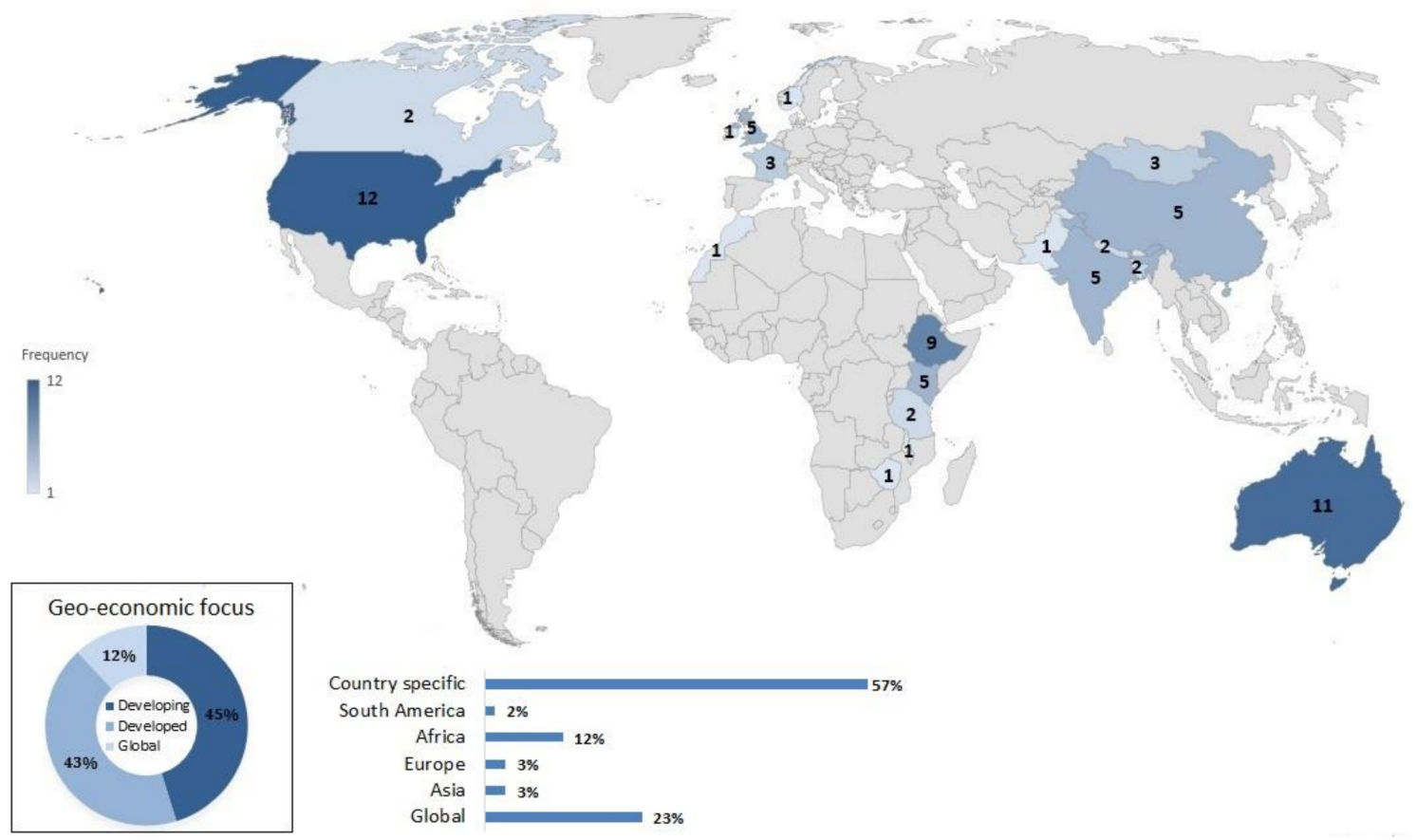

Figure 3. Geographical distribution of the reviewed publications by study area and geo-economic focus, $N=126$. (The intensity of color indicates the frequency of studies per country) (Powered by Bing®DSAT for MSFT, GeoNames, Microsoft, Navteq, Thinkware Extract, Wikipedia).

\subsection{Production Systems}

We classified the focus on publications by production systems using the Food and Agriculture Organization of the United Nations (FAO) classification (see Figure 4). More than half (55\%) covered solely livestock systems in which more than $90 \%$ of dry matter fed to animals comes from rangelands, pastures, annual forages, and purchased feeds, and $10 \%$ or less of the dry matter eaten by animals is provided by crop production. This system covers two sub-classification: the landless $(14 \%)$ and the grassland-based (86\%) systems. Publications under grassland-based systems considered pastoral farming from African countries, and extensive grazing particularly for small ruminants, whilst rangelands and intensive grazing conditions were investigated in Australia and the United States (see Supplementary Materials S2 for complete list).

About $15 \%$ of the publications were about mixed crop-livestock farming systems in which animals are fed mostly on dry matter from crop by-products or at least $10 \%$ of the total value of production comes from non-livestock farming activities such as crop production. Almost all of the publications in this system were from developing countries or regions where the system is described as agropastoral, which means that in addition to pastoral farming, crop cultivation is integrated, and crop residues are provided to livestock [40]. In terms of system descriptions, we found limited information by which to identify the specific sub-systems under mixed farming as rain-fed or irrigated. Additionally, while $18 \%$ 
of publications were presented in a form of a sector-wide overview pertaining to livestock, $12 \%$ were not associated with a specific type of system.

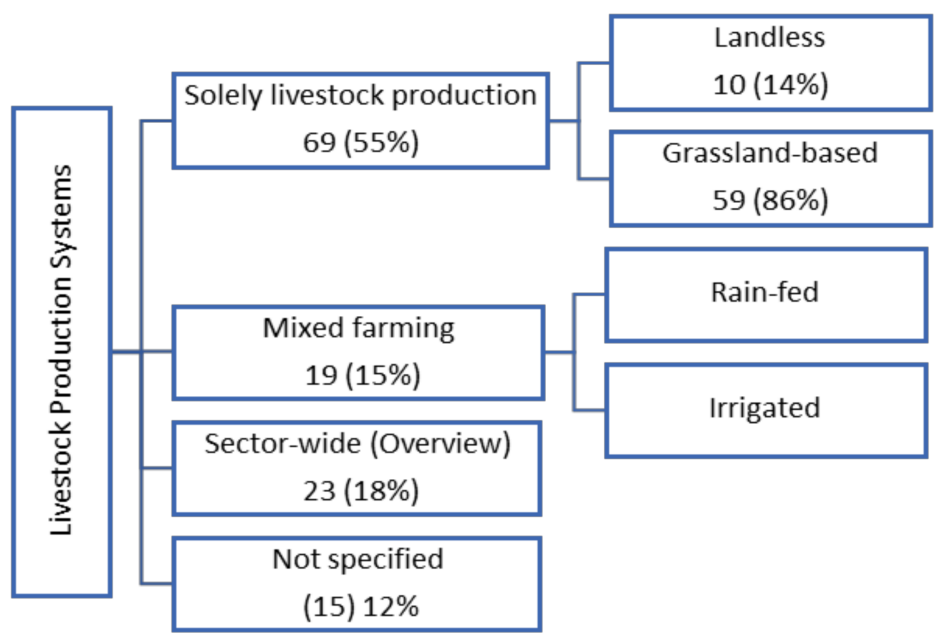

Figure 4. Focus of reviewed publication classified by production systems, $(N=126)$.

\subsection{Livestock Types}

The majority of the publications covered multiple livestock types at a time, and a few covered specific types, such as camels (4\%), ass and donkeys (4\%), and yaks (3\%). About $71 \%$ from total publications were focused on ruminants, classified further into large (62\%) and small (38\%) ruminants. Cattle was identified as the most studied species ( $25 \%$ from total publications) in addition to publications directed at dairy $(9 \%)$ and meat or beef-type $(7 \%)$. There were also a few that dealt with water buffaloes (3\%). The studies on small ruminants (27\% from total publications), consisted of $56 \%$ on sheep and $44 \%$ on goats. Around $19 \%$ considered monogastric animals, including poultry, mainly chickens $(13 \%)$ and pigs $(6 \%)$.

\subsection{Climate Parameters}

The main climate parameters that were studied in the reviewed publications were increasing temperatures $(78 \%)$, followed by rainfall or precipitation variability (63\%) (Table 1). Multiple climate change related extreme weather events were investigated in $82 \%$ of total publications, mainly drought $(50 \%)$, extreme weather in general (37\%), extreme heat $(36 \%)$, increasing occurrences of floods $(17 \%)$, and more intense typhoons or cyclones $(6 \%)$.

Table 1. Livestock exposure to the different climatic variables, $N=126$.

\begin{tabular}{ccc}
\hline Climate Parameter & Number of Publications & \% of Total \\
\hline Increasing temperature & 98 & 78 \\
Rainfall variability & 80 & 63 \\
Drought & 63 & 50 \\
Weather extremes (general) & 47 & 37 \\
Extreme heat & 45 & 36 \\
Flood & 21 & 17 \\
Typhoon & 8 & 6 \\
\hline
\end{tabular}

\subsection{Main Impacts}

We found eleven different production areas (Table 2) that were investigated and found to be affected by climate change. These were: feeds (mentioned in 52\% of the publications), diseases $(43 \%)$, economic $(36 \%)$, water and land resources (35\%), production (32\%), heat stress $(23 \%)$, livestock 
numbers $(22 \%)$, reproduction (22\%), biodiversity $(13 \%)$, food security $(13 \%)$, and product quality $(10 \%)$ (see Figure 5).

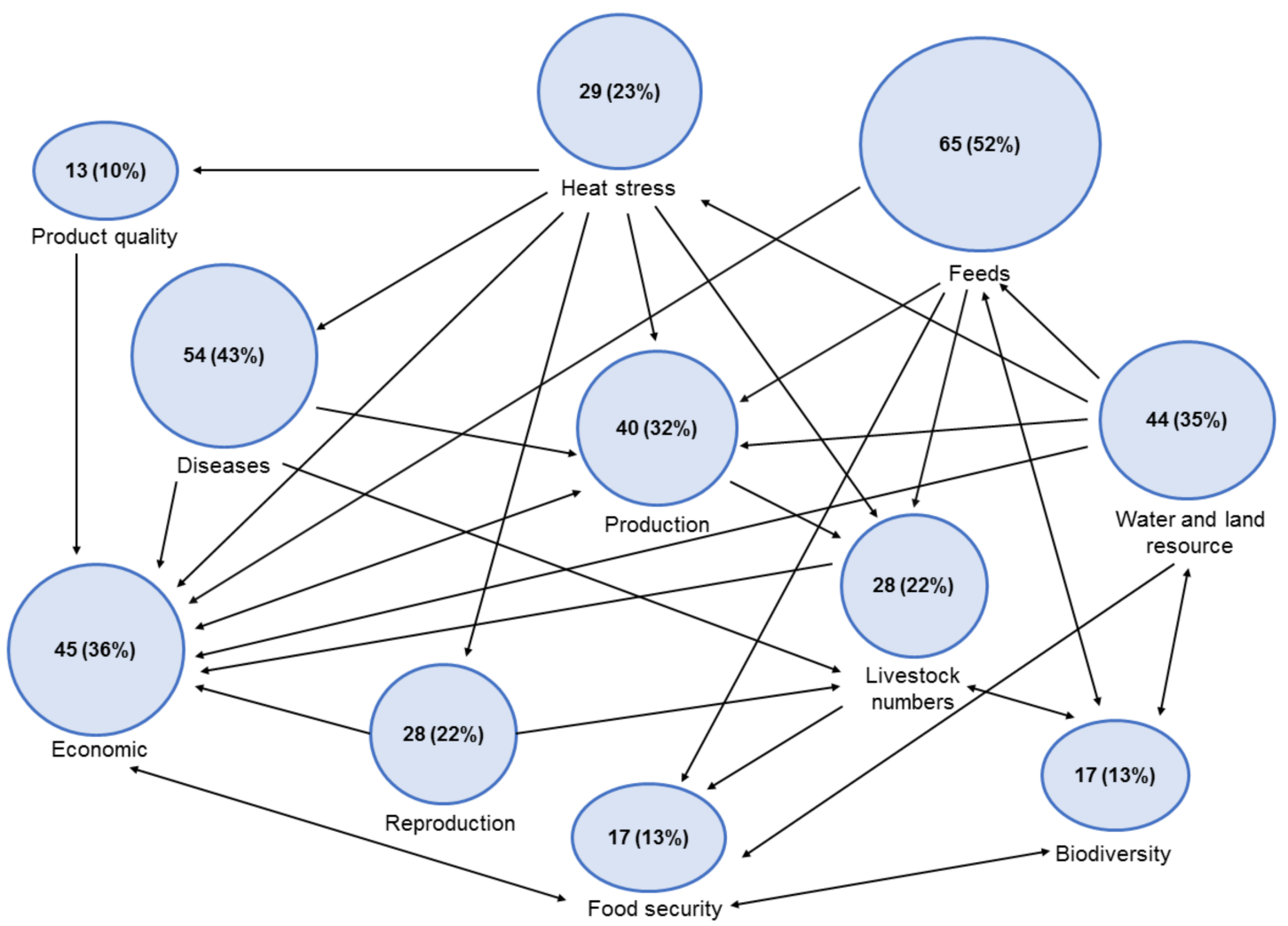

Figure 5. Representation of the complex and interacting climate change impacts on livestock. (Bubble size represents impact domains in proportion to the number of studies and percent of total reviewed publications. The one-way arrow $(\rightarrow)$ directly points one impact domain to another, while the double-headed arrow $(\leftrightarrow)$ represents two-way interaction of the two impact domains).

Of the publications, $92 \%$ simultaneously looked at multiple impacts to the different production areas, while a few focused on a single impact alone, including specific discussions on diseases (e.g., [41-43]) and on feeds (e.g., [44-47]). The emerging pattern of interactions of these different impact focal areas implies that climate change affects livestock in many ways-from one production aspect leading to a complex interaction with one or more other production areas.

Further analyses of content showed other notable findings: (1) almost all of the impact areas (nine out of eleven) examined had a further effect on the economic aspects of livestock production; (2) heat stress directly impacts animals through aspects such as production, reproduction, livestock numbers, disease occurrences, and product quality; (3) production aspects and livestock numbers were most likely affected by the indirect effects of heat stress, diseases, reproduction, production, and feeds; and (4) other impact domains are interconnected or associated from one to another, such as water and land resources to biodiversity, and economic impacts to food security. The reported effects of climate change on livestock are summarized in Table 2. 
Table 2. Summary of climate change impacts on livestock from reviewed publications, $N=126$.

\begin{tabular}{|c|c|}
\hline Impact Domain & Specific Climate Change Impacts Reported \\
\hline Feeds & $\begin{array}{l}\text { - } \quad \text { Decline in pasture, rangelands, crops, and forages productivity } 1,3,5,6 \\
\text { - } \\
\text { - }\end{array}$ \\
\hline Diseases & 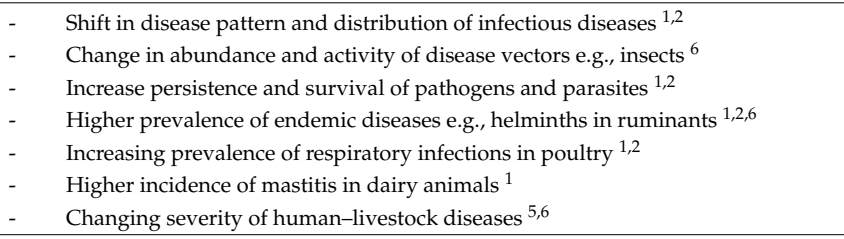 \\
\hline Economic & $\begin{array}{ll}\text { - } & \text { Increased risk of pastoralist household livelihoods } 1,3,5 \\
\text { - } & \text { Reduce cashflow and decrease savings of herders } 3,4 \\
\text { - } & \text { High price volatility and high transaction costs, e.g., disease outbreaks } \\
\text { - } & \text { Trade issues, more problematic grain supply and trading pattern competitors } \\
\text { - } & \text { Loss of farm profits, e.g., egg production and dairy cattle } \\
\text { - } & \text { Increase in cost of labor and unemployment within rural regions } \\
\text { - } & \text { Decline in product prices and net value of animal stocks, e.g., beef and lamb } \\
\end{array}$ \\
\hline Water and land resource & $\begin{array}{l}\text { - } \quad \text { Increases competition and conflicts to grass and water access }{ }^{1,3} \\
\text { - } \\
\text { - }\end{array}$ \\
\hline Production & $\begin{array}{ll}\text { - } & \text { Decline in milk yield and meat production }{ }^{1,3} \\
\text { - } & \text { Low production efficiency in poultry and cattle }{ }^{1} \\
\text { - } & \text { Reduced wool production }{ }^{1,3} \\
\text { - } & \text { Poor growth and live weight losses e.g., beef cattle and sheep }{ }^{1,3,5}\end{array}$ \\
\hline Heat stress & 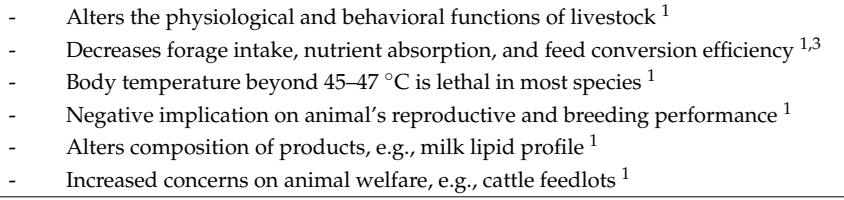 \\
\hline Livestock numbers & $\begin{array}{ll}\text { - } & \text { Higher livestock death in pastoral system }{ }^{4} \\
\text { - } & \text { Disproportionate decrease in stocking rates }{ }^{1,3} \\
\text { - } & \text { Increased in still births, embryo mortality, and abortions }{ }^{1,3} \\
\text { - } & \text { Recorded } 3000 \text { goats and sheep and } 500 \text { yaks death in Northern Pakistan }{ }^{1,3} \\
\text { - } & \text { Increasing camel calf mortality } 1,3 \\
\text { - } & \text { Higher rates of preslaughter mortality in broiler chickens }{ }^{1} \\
\end{array}$ \\
\hline Reproduction & $\begin{array}{ll}\text { - } & \text { Decrease in reproductive performance, e.g., lower conception rates }{ }^{1,5} \\
\text { - } & \text { Decrease in animal fertility, general fitness and longevity } 1,5 \\
\text { - } & \text { Reduced birthing rates, increases in age at first calving in beef cattle }{ }^{1,5}\end{array}$ \\
\hline Food security & $\begin{array}{l}\text { - } \quad \text { Increase number of people not receiving enough food to maintain healthy life } 5,6 \\
\text { - } \\
\text { - }\end{array}$ \\
\hline Biodiversity & $\begin{array}{ll}- & \text { Genetic biodiversity loss }{ }^{6} \\
- & \text { Population reduction of rare breeds } s^{1,6} \\
- & \text { Species and breed displacements } \\
\text { - } & \text { Predation of livestock by wildlife } \\
\text { - } & \text { Reduced synergy between crop-livestock } \\
\end{array}$ \\
\hline Product quality & $\begin{array}{ll}\text { - } & \text { Negative influence on quality of fur, wool, and cashmere }{ }^{5} \\
\text { - } & \text { Results to lower average egg weight and poor egg shell quality } 1,5 \\
\text { - } & \text { Affects nutritional contents of livestock products }{ }^{5} \\
\text { - } & \text { Impacts carcass fatness, meat flavor/taste and tenderness in beef cattle }{ }^{5} \\
\text { - } & \text { Observed greater reductions in milk quality, e.g., dairy goats }{ }^{5} \\
\text { Increasing number of carcass condemnation }{ }^{5}\end{array}$ \\
\hline
\end{tabular}

As it links to climate parameters: ${ }^{1}$ temperature; ${ }^{2}$ rainfall/precipitation variation; ${ }^{3}$ drought; ${ }^{4}$ extreme events;

${ }^{5}$ multiple climate variables; ${ }^{6}$ global climate changes (general).

\subsection{Adaptive Responses}

Following Kates et al.'s [48] adaptation concepts and Herrero et al.'s [17] proposed classification of adaptation options for livestock, adaptive responses were explicitly reported in existing publications (see summary list in Table 3). Incremental adaptation through technical and management improvements occurred as the most common response. These were particularly noted in local-scale 
case studies from developing countries (e.g., [49,50]). A few studies focus to a lesser extent on systemic adaptation options such as altering farming systems components, institutional and policies changes (e.g., [11,51]), and involving the socio-economic dynamics of livestock farming systems (e.g., [52,53]). Transformations not just of production systems but of farmers livelihoods have evolved as another adaptation option in livestock systems. Some examples include the shifting in choice of livestock in addition to, or the replacement to, other species, and moving from cropping to livestock farming in response to a changing rainfall and more frequent drought occurrences (e.g., $[10,54])$. There was no further information found from these studies as to further evaluations of such transformational adaptation.

Table 3. Summary of adaptation options in livestock from existing publications, $N=126$.

\begin{tabular}{|c|c|}
\hline Adaptation Options & Constraints to Adoption \\
\hline $\begin{array}{l}\text { Incremental } \\
\text { Improvement in quality and quantity of feeds: } \\
\text { - } \quad \text { Improved pasture yield: revival of traditional one pasture only for the length of one } \\
\text { season, restoration of degraded pasture, increased vegetation cover, rehabilitation of } \\
\text { pasture water supply, development of irrigated pasture, modifying the schedule of grazing } \\
\text { (measures from Mongolian livestock sector) } \\
\text { Adjustment in feeding system management: livestock stocking rate adjustment (US cattle } \\
\text { raisers), planting perennial forage crops, feed supplementation (from Asia mixed-crop } \\
\text { livestock system) } \\
\text { Altering rangeland management: revision of fertiliser management (sown legumes and } \\
\text { phosphate), greater use of spell and rotational grazing and attention to fire management, } \\
\text { constant conservative stocking rate, pasture-climate scenario simulations (from Australian } \\
\text { livestock systems) } \\
\text { Land and water use efficiency: } \\
\text { - } \\
\text { - } \\
\text { Ehange in farmland use, pasture irrigation (from US and Australia systems) } \\
\text { Alleviation of heat stress: } \\
\text { - } \quad \text { Provision of shade (natural shading material from trees or artificial cooling systems) } \\
\text { Improved housing systems ventilation systems } \\
\text { Direct access to water source such as rivers and pools } \\
\text { - } \\
\text { Selection of heat tolerant animal species and breeds } \\
\text { Livestock management: } \\
\text { - Adopting livestock healthcare practices } \\
\text { - } \\
\text { - } \\
\text { - }\end{array}$ & $\begin{array}{l}\text { Rangelands: } \\
\text { - } \quad \text { Bio-physical barriers and direction social and } \\
\text { economic parameters } \\
\text { - } \quad \text { Uncertainty in climate change science } \\
\text { Mixed systems: } \\
\text { - } \quad \text { Lack of information at the systems level, e.g., } \\
\text { difficulty in modelling crop-livestock impacts at } \\
\text { spatial and temporal scale, complex farming } \\
\text { context (biophysical, socio-economic and } \\
\text { cultural). } \\
\text { - Capacity building highly dependent on } \\
\text { government and other institutions } \\
\text { - Pastoral systems: } \\
\text { - Typical communal land tenure systems } \\
\text { - } \quad \text { Limited and insecure access to natural, capital } \\
\text { and labour resources } \\
\text { - } \quad \text { Poor market infrastructure and organisation } \\
\text { - Cultural factors and farmers disposition }\end{array}$ \\
\hline 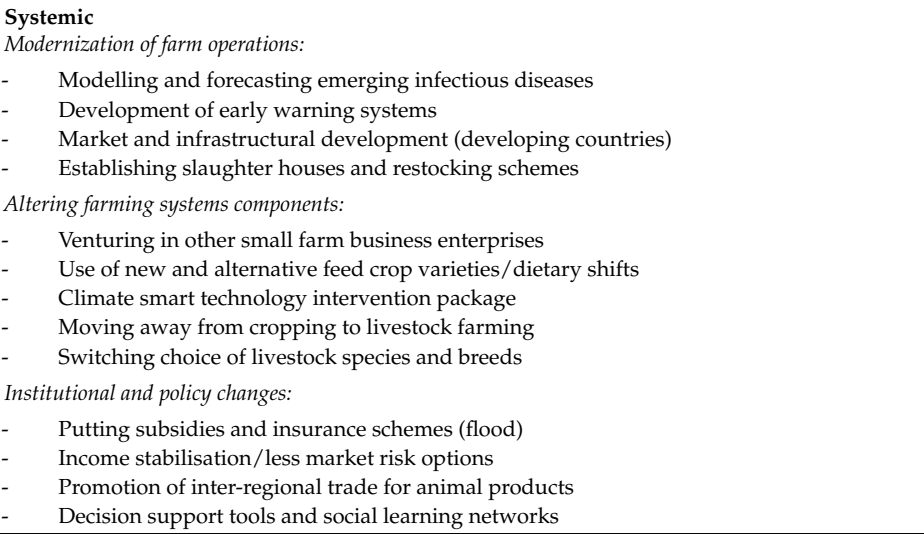 & 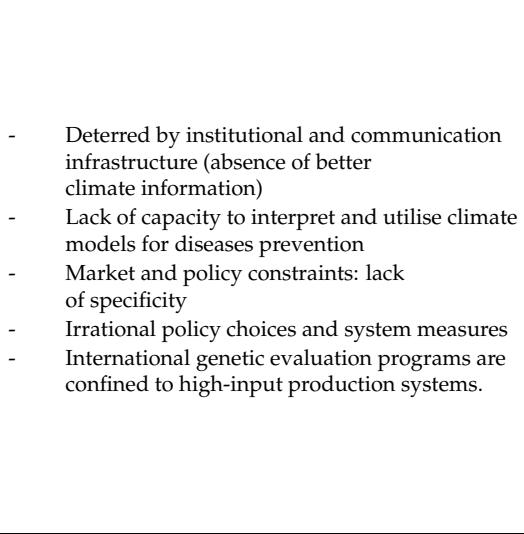 \\
\hline $\begin{array}{l}\text { Transformational } \\
\text { Farming system transitions: } \\
\text { - } \quad \text { Migration to higher altitudes, location shift because of alternate source of income, change } \\
\text { in migration timing, leaving pastoralism altogether (Pastoral systems in Africa) } \\
\text { - } \quad \text { Geographic relocation of confined livestock facilities } \\
\text { Diversification: } \\
\text { - } \quad \text { Livelihood and off-farm income options } \\
\text { - } \quad \text { Livestock herd-mix, multi-species herding } \\
\text { Production intensification: } \\
\text { - } \quad \text { Increases in industrial systems }\end{array}$ & $\begin{array}{ll}\text { - } & \text { Weakly enforced institutional mechanisms } \\
\text { (developing countries) } \\
\text { - }\end{array}$ \\
\hline
\end{tabular}




\section{Discussion}

This systematic review reveals a growing research interest on climate change impacts and adaptation on livestock from different production systems, geographical, and agroecological contexts. The extent and distribution of the studies reflect the importance of livestock to various countries and regions, and the fundamental need to address and adapt to the identified impacts of climate change. Although the impacts of climate change on livestock have not received as much attention as those of crops [17], several authors have documented key impact domains in livestock systems $[15,23,26,27]$ (see also summary in Table 2). Systematic documentation of these different impacts is important in determining which aspect of livestock production is under most pressure, and consequently, the most that needs relevant adaptation.

\subsection{Climate Change Impacts on Livestock}

In this section, we discuss the five production areas that were reported to be affected mainly by climate change: feeds, diseases, economic, production related, and water and land usage in livestock (see Figure 5). Feeds related impacts of climate change are commonly described in terms of quantity and quality $[23,26,27]$. Decline in quantity of pasture, rangeland, and forage crops production are widely mentioned as consequence of increased temperature and droughts [46,47,55]. A shift in seasonal patterns, from hotter and drier climates, causes significant yield reductions and alterations in the temporal pattern of grassland production and grazing systems [30,56]. Increasing temperatures decrease pasture production, and result in poorer quality of forage species [29,31]. Similarly, higher temperatures are associated with increased lignification in plant tissues and decreased digestibility of forage directly affecting forage supply $[8,47]$. Lower forage quality means that animals may not fulfil the energy requirement to maintain their body weight [26].

Livestock diseases are highly affected by climate changes. The impacts are mostly expressed in terms of severity and distribution, and described as either direct or indirect. Direct impacts on animal health are mainly because of exposure to increased temperatures and humidity. The main direct impacts reported include reduced immunity to infections (e.g., due to heat stress), increased development rates of pathogens, and prevalence of infectious diseases during extreme weather events [6,57]. Indirect impacts are attributed to variations in temperature and rainfall, which included increase in persistence and abundance of disease vectors and parasites, host resistance to infectious agents, and changes in the severity of human-livestock diseases [41,58]. Moreover, several authors identified extreme examples of climate driven livestock diseases, such as ruminants' helminthological infections [42] (e.g., nematode infections in cattle [43]), avian influenza [59], higher clinical mastitis incidence in dairy cows [60], and parasitic diseases (e.g., movement of tick-borne infestations [61]).

Economic impacts arise from poorer performance of animals, which are associated with impacts on other production aspects, such as in feeds and health. In pastoral systems, for example, economic losses are usually linked to poor animal performance due to feed scarcity induced by droughts [62]. Recurrent economic losses in pastoral systems are increasing livelihood and food security risks of many pastoral households in Africa [63,64]. In intensive systems, economic impacts arise through affected trade, such as shortages in feed grain supply due to reduced harvest during droughts $[65,66]$. Apparently, disease outbreaks and heat stress directly impact expenses and incomes, and can cause decline and instability in prices and net values of animal stocks [67-70]. Additionally, many studies report extreme weather events such as cyclones, floods, and droughts to directly impact animal stocks by increased morbidity and death rates [26,71].

Production related impacts of climate change are accounted for with greater concern on the associated performance parameters such as daily weight gain, feed conversion efficiency, and milk yields and quality among others [15,72,73]. Heat stress and humidity alter the physiology of livestock, making animals more susceptible to disease and stress [68,74]. Variability in temperatures result in pronounced impacts on reproductive performance of animals such as decreased fertility, conception rate, and longevity [74]. 
Water and land resources are key inputs in livestock production systems, mainly in feed crops production $[17,23,26]$. The livestock sector uses $8 \%$ of global water use [27]. Climate change affects water availability, and water scarcity and depletion are reported to seriously reduce livestock productivity.

\subsection{Research Gaps and Needs}

Although the research on climate change impacts and adaptation in livestock systems is generally increasing, we identified five research gaps and needs.

\subsubsection{The Need to Widen Spatial Coverage}

The number of publications is not representative with respect to the sensitivity to climate change and vulnerability contexts of different regions and production systems. In terms of spatial coverage, $12 \%$ of publications considered global scale, while the share of studies from developing $(45 \%)$ and developed (43\%) countries or regions is about the same. Livestock in developing countries contributes a much higher share to people's income and has important socio-economic roles [13,21]. Moreover, developing countries are more vulnerable to climate change impacts and livestock are more likely to be exposed to extreme events, with little infrastructure and resources to keep animals safe. Therefore, more research in developing countries is needed. There is a fundamental research gap in Central and South America, Southeast Asia, the Pacific islands, and in parts of Africa, with more than half (56\%) concentrated in East Africa (see Figure 3). In drier areas of Central and South America, it is expected that climate change will likely worsen drought and the degradation of agricultural land, decreasing the productivity of livestock and important feed crops such as maize and soybeans, with adverse consequences for food security [75]. In Southeast Asia, up to a $20 \%$ decrease in crop yield is projected by 2050 , as a result of regional changes in temperate and precipitation, thereby impacting feeds and fodder availability for livestock. With Asians population growth and the increasing demand in higher standards of living, this decrease could adversely impact more than a billion people by 2050 [76]. The same applies to Pacific islands, which are highly vulnerable to extreme weather events and sea level rise, and where, by 2050, climate change is projected to limit freshwater resources, which are a very crucial resource in livestock production [77].

\subsubsection{The Need for Holistic Research at the Impact and Adaptation Nexus}

Adaptation responses are mainly documented as a synthesis of what is already being done, the measures undertaken, or is continuing across different production systems. These are generic autonomous adaptation responses that take little or no account to specific climate change impacts. Only a few have clearly associated adaptations to certain climate change impacts (e.g., [56,62,78]). To develop effective adaptation strategies and ensure adaptation success, research on climate change adaptation must not be approached separately, but should instead be integrated within the framework of impact assessments [79,80].

The documented adaptation responses are mostly incremental through management and technology adjustments to reduce the impacts, and less on systemic measures such as institutional and policy changes. More research on anticipatory adaptation is needed, targeted for specific impacts, especially in developing countries where predictions on climate change impacts are grim and many farmers are constrained to spontaneous responses even in cases of extreme events, rather than being able to develop planned adaptation. Moreover, there is no adaptation option that stands out as having high potential, without considering local conditions and realities [81]. For example, under the same grassland-based systems, the intensive rangelands and pastoral systems occur in a contrary social and economic conditions and faces different challenges, thus different methodological assessments may apply. Limited evidence accounting for social variables have been similarly raised as concerns and need to be considered further in climate change adaptation researches [17]. 


\subsubsection{The Need for More Research on Mixed Crop-Livestock Production Systems}

Reviewed studies mainly focus on grassland-based production systems ( $47 \%$ of total publication). There is a need for research on climate change impacts and adaptation in mixed crop-livestock systems. Half of the world's food is produced in mixed crop-livestock systems [82]. This production system sustains most household livelihoods in developing regions [83], and research in this area can have serious implications on the sustainability of mixed crop-livestock production, and the sustenance of farmers' livelihoods under changing climate.

\subsubsection{The Need to Include Monogastric Livestock}

The majority of reviewed publications (71\%) are on ruminants while monogastric livestock, particularly pigs and chickens, receive much less attention. Pig and poultry farming, however, are important to many farmers in developing countries and regions, as they can co-exist in any agricultural system [84]. Monogastric animals' health is more susceptible to climate change and productivity is even more affected than that of ruminants [26]. Furthermore, pigs and poultry have lower environmental impacts than ruminants, and local chicken and pig breeds have an increased potential in the future because of their unique characteristics in adapting to climate change [85]. Ruminants are crucial in pastoral and subsistence production as a main source of food in areas that cannot sustain crop production due to long period of droughts and water scarcity (e.g., [52]). Thus, while there is a need for more research on monogastrics, ruminant production will remain important under a changing climate in areas where pig and poultry farming might become impossible.

\subsubsection{The Need for More Quantitative Research Including Yield Impact Models}

There is a research gap on quantitative approaches in assessing climate change impacts and adaptation in livestock systems, and predicting the future of the livestock sector under different climate change scenarios. Only a few studies (mainly from developed countries) provide primary evidence of impacts of climate change using relevant quantitative analysis, vulnerability, and adaptations contexts (e.g., [86,87]). For example, as most adaptation incurs costs, publications could have covered quantitative analysis of the relative costs and benefits of potential adaptation strategies, but instead, very limited information was found (e.g., [5,78]). In developing countries, however, the reason for relatively few quantitative studies might be the complexities of socio-demographic and economic factors, and the lack of long-term and reliable data in these areas. This may further reflect some key constraints in adaptation, such as the lack of capacities and capital $[17,88]$, and the relatively lower quality of climate information and communications [81,89]. This is of particular concern given the identified evidence that strongly suggests that climate change impacts will be more severe in these developing countries, where smallholders and poor livestock keepers are likely to be found [90]. Moreover, simulations and experimentation of livestock physiology and its potential to reduce the impacts are lacking. With the diversity of livestock systems, more impact assessment studies are also needed which consider direct quantification of productivity losses, including yield, vis-à-vis livestock species and production systems. While there is already some evidence on how climate change affects livestock yield (meat and milk) $[15,30,56,72,73]$, we found gaps in the systematic understanding of how and by how much the yield is reduced in different livestock management systems.

\subsection{Limitations}

The systematic literature review excluded non-English documents and publications other than peer-reviewed articles, such as grey literature. These exclusions may have led to a selection bias and, therefore, an underestimation of the overall climate-related impact on livestock systems. However, the overall conclusions from our review suggest similar findings across the identified publications. Therefore, we believe the review is valuable in corroborating evidence. The exclusion of mitigation and issues relating to livestock contributing to climate change may have led to an overestimation of 
the importance of adaptation and we might have lost sight of the overall context in which livestock sector will develop in the future.

\section{Conclusions}

Livestock production remains one of the world most important quandaries. On the one hand there is an ever increasing demand for animal-based products, and on the other hand the impact on climate change on livestock production, particularly in developing regions, and the negative contribution of livestock to a changing climate. The livestock sector has to become more sustainable while adapting to climate change and at the same time meeting the demands of the growing population for animal-based products. There are substantial research gaps in how livestock is impacted by climate change and how farmers and systems adapt, particularly at the impact and adaptation nexus. We provided results of a systematic literature review and revealed five research gaps, which when addressed can draw out policies and practices to support livestock-keepers in adapting to climate change more effectively. An important implication of our review is if the magnitude of climate change impacts is not known, the capacity to respond or adapt will be underestimated. More detailed adaptation research is needed, such as developing more adaptation options from various levels to inform local, national, and regional policy impacts. Adaptation will be planned and appropriated accordingly to livestock, provided such evidence is established. Likewise, with adaptation, livestock can ascertain its role in achieving food security under climate change.

Supplementary Materials: The following are available online at http:/ / www.mdpi.com/2225-1154/6/3/54/s1, S1: Data parameters extracted and coded as nodes, cases, and classifications. S2: Publications included in the analysis.

Author Contributions: J.F.E. conducted the systematic review, analyzed the data, drafted the manuscript; J.A.L. advised on the conceptualization of this paper, reviewed part of the literature and made essential edits on multiple versions of this paper; K.K.Z. advised on the analysis and interpretation of data and made comprehensive edits and critical revision of the manuscript.

Funding: This paper was conducted as part of a PhD project financially supported by Charles Darwin University in Darwin, Australia.

Acknowledgments: We would like to thank the editor and the two anonymous reviewers for their thoughtful comments which improved earlier version of the manuscript.

Conflicts of Interest: The authors declare no conflict of interest.

\section{References}

1. Thornton, P.K. Livestock production: Recent trends, future prospects. Philos. Trans. R. Soc. B Biol. Sci. 2010, 365, 2853-2867. [CrossRef] [PubMed]

2. Delgado, C.L. Rising consumption of meat and milk in developing countries has created a new food revolution. J. Nutr. 2003, 133, 3907s-3910s. [CrossRef] [PubMed]

3. FAO. The Impacts of Disasters on Agriculture and Food Security. The Food and Agriculture Organisation of the United Nations, 2015. Available online: http:/ / www.fao.org/3/a-i5128e.pdf (accessed on 14 September 2017).

4. FAO. Food and Agriculture: Key to Achieving the 2030 Agenda for Sustainable Development. The Food and Agriculture Organisation of the United Nations, 2016. Available online: http:/ / www.fao.org/documents / card/en/c/d569c955-8237-42bf-813e-5adf0c4241b9/ (accessed on 20 September 2017).

5. Weindl, I.; Hermann, L.C.; Alexander, P.; Christoph, M.; Petr, H.; Mario, H.; Christoph, S.; Susanne, R. Livestock in a changing climate: Production system transitions as an adaptation strategy for agriculture. Environ. Res. Lett. 2015, 10, 094021. [CrossRef]

6. Bett, B.K.; Gachohi, J.; Sindato, C.; Mbotha, D.; Robinson, T.; Lindahl, J.; Grace, D. Effects of climate change on the occurrence and distribution of livestock diseases. Prev. Vet. Med. 2017, 137, 119-129. [CrossRef] [PubMed]

7. Morignat, E.; Perrin, J.B.; Gay, E.; Vinard, J.L.; Calavas, D.; Hénaux, V. Assessment of the impact of the 2003 and 2006 heat waves on cattle mortality in France. PLoS ONE 2014, 9, e93176. [CrossRef] [PubMed] 
8. Giridhar, K.; Samireddypalle, A. Impact of climate change on forage availability for livestock. In Climate Change Impact on Livestock: Adaptation and Mitigation; Springer: Berlin, Germany, 2015; pp. 97-112.

9. World Bank. Povcalnet: The On-Line Tool for Poverty Measurement. Development Research Group of the World Bank, 2015. Available online: http:/ /iresearch.worldbank.org/PovcalNet/index.htm?1 (accessed on 14 September 2017).

10. Prasad, C.S.; Sejian, V. Climate change impact on livestock sector: Visioning 2025. In Climate Change Impact on Livestock: Adaptation and Mitigation; Springer: Berlin, Germany, 2015; pp. 479-489. [CrossRef]

11. Descheemaeker, K.; Oosting, S.J.; Homann-Kee Tui, S.; Masikati, P.; Falconnier, G.N.; Giller, K.E. Climate change adaptation and mitigation in smallholder crop-livestock systems in Sub-Saharan Africa: A call for integrated impact assessments. Reg. Environ. Chang. 2016, 16, 2331-2343. [CrossRef]

12. Seo, S.N.; Mendelsohn, R.; Dinar, A.; Kurukulasuriya, P. Adapting to climate change mosaically: An analysis of African livestock management by agro-ecological zones. BE J. Econ. Anal. Policy 2009, 9. [CrossRef]

13. Thornton, P.K.; Gerber, P.J. Climate change and the growth of the livestock sector in developing countries. Mitig. Adapt. Strateg. Glob. Chang. 2010, 15, 169-184. [CrossRef]

14. Seo, S.N.; McCarl, B.A.; Mendelsohn, R. From beef cattle to sheep under global warming? An analysis of adaptation by livestock species choice in South America. Ecol. Econ. 2010, 69, 2486-2494. [CrossRef]

15. Rust, J.M.; Rust, T. Climate change and livestock production: A review with emphasis on Africa. S. Afr. J. Anim. Sci. 2013, 43, 256-267. [CrossRef]

16. Thornton, P.K.; Herrero, M. Climate change adaptation in mixed crop -livestock systems in developing countries. Glob. Food Secur.-Agric. Policy Econ. Environ. 2014, 3, 99-107. [CrossRef]

17. Herrero, M.; Wirsenius, S.; Henderson, B.; Rigolot, C.; Thornton, P.K.; Havlík, P.; De Boer, I.; Gerber, P.J. Livestock and the environment: What have we learned in the past decade? Annu. Rev. Environ. Resour. 2015, 40, 177-202. [CrossRef]

18. Porter, J.R.; Xie, L.; Challinor, A.J.; Cochrane, K.; Howden, S.M.; Iqbal, M.M.; Lobell, D.B.; Travasso, M.I. Food security and food production systems. In Climate Change 2014: Impacts, Adaptation, and Vulnerability. Part A: Global and Sectoral Aspects; IPCC AR5 WGI; Cambridge University Press: Cambridge, UK, 2014; Chapter 7, pp. 485-533.

19. Herrero, M.; Thornton, P.K. Livestock and global change: Emerging issues for sustainable food systems. Proc. Natl. Acad. Sci. USA 2013, 110, 20878-20881. [CrossRef] [PubMed]

20. Pica-Ciamarra, U.; Baker, D.; Morgan, N.; Zezza, A.; Azzarri, C.; Ly, C.; Nsiima, L.; Nouala, S.; Okello, P.; Sserugga, J. Investing in the Livestock Sector: Why Good Numbers Matter, a Sourcebook for Decision Makers on How to Improve Livestock Data; FAO: Rome, Italy, 2014.

21. Robinson, T.P.; Wint, G.R.W.; Conchedda, G.; Van Boeckel, T.P.; Ercoli, V.; Palamara, E.; Cinardi, G.; D'Aietti, L.; Hay, S.I.; Gilbert, M. Mapping the global distribution of livestock. PLoS ONE 2014, 9, e96084. [CrossRef] [PubMed]

22. Steinfeld, H.; Wassenaar, T.; Jutzi, S. Livestock production systems in developing countries: Status, drivers, trends. Rev. Sci. Technol. 2006, 25, 505-516. [CrossRef]

23. Thornton, P.K.; van de Steeg, J.; Notenbaert, A.; Herrero, M. The impacts of climate change on livestock and livestock systems in developing countries: A review of what we know and what we need to know. Agric. Syst. 2009, 101, 113-127. [CrossRef]

24. Gandini, G.C.; Villa, E. Analysis of the cultural value of local livestock breeds: A methodology. J. Anim. Breed. Genet. 2003, 120, 1-11. [CrossRef]

25. Upton, M. The Role of Livestock in Economic Development and Poverty Reduction. Food and Agriculture Organization of the United Nations (FAO), 2004. Available online: http:/ / www.fao.org/docrep/015/i2744e/ i2744e00.pdf (accessed on 15 September 2017).

26. Nardone, A.R.; Ronchi, B.; Lacetera, N.; Ranieri, M.S.; Bernabucci, U. Effects of climate changes on animal production and sustainability of livestock systems. Livest. Sci. 2010, 130, 57-69. [CrossRef]

27. Rojas-Downing, M.M.; Nejadhashemi, A.P.; Harrigan, T.; Woznicki, S.A. Climate change and livestock: Impacts, adaptation, and mitigation. Clim. Risk Manag. 2017, 16, 145-163. [CrossRef]

28. Herrero, M.; Addison, J.; Bedelian, C.; Carabine, E.; Havlik, P.; Henderson, B.; Van De Steeg, J.; Thornton, P.K. Climate change and pastoralism: Impacts, consequences and adaptation. OIE Rev. Sci. Tech. 2016, 35, 417-433. [CrossRef] [PubMed] 
29. Leister, A.M.; Paarlberg, P.L.; Lee, J.G. Dynamic effects of drought on U.S. Crop and livestock sectors. J. Agric. Appl. Econ. 2015, 47, 261-284. [CrossRef]

30. Lunt, I.D.; Jansen, A.; Binns, D.L. Effects of flood timing and livestock grazing on exotic annual plants in riverine floodplains. J. Appl. Ecol. 2012, 49, 1131-1139. [CrossRef]

31. Polley, H.W.; Briske, D.D.; Morgan, J.A.; Wolter, K.; Bailey, D.W.; Brown, J.R. Climate change and north american rangelands: Trends, projections, and implications. Rangel. Ecol. Manag. 2013, 66, 493-511. [CrossRef]

32. Mulrow, C.D. Rationale for systematic reviews. BMJ Br. Med. J. 1994, 309, 597. [CrossRef]

33. Liberati, A.; Altman, D.G.; Tetzlaff, J.; Mulrow, C.; Gøtzsche, P.C.; Ioannidis, J.P.A.; Clarke, M.; Devereaux, P.J.; Kleijnen, J.; Moher, D. The prisma statement for reporting systematic reviews and meta-analyses of studies that evaluate healthcare interventions: Explanation and elaboration. BMJ 2009, 339. [CrossRef] [PubMed]

34. Crane, T.A.; Delaney, A.; Tamás, P.A.; Chesterman, S.; Ericksen, P. A systematic review of local vulnerability to climate change in developing country agriculture. Wiley Interdiscip. Rev. Clim. Chang. 2017, 8, e464. [CrossRef]

35. Phalkey, R.K.; Aranda-Jan, C.; Marx, S.; Höfle, B.; Sauerborn, R. Systematic review of current efforts to quantify the impacts of climate change on undernutrition. Proc. Natl. Acad. Sci. USA 2015, 112, E4522-E4529. [CrossRef] [PubMed]

36. Horsley, T.; Dingwall, O.; Tetzlaff, J.M.; Sampson, M. Checking reference lists to find additional studies for systematic reviews. Cochrane Database Syst. Rev. 2009. [CrossRef]

37. Bazeley, P. Qualitative Data Analysis with Nvivo, 2nd ed.; Bazeley, P., Jackson, K., Eds.; SAGE: London, UK, 2013.

38. Pope, C.; Mays, N.; Popay, J. Synthesising Qualitative and Quantitative Health Evidence: A Guide to Methods; McGraw-Hill Education: London, UK, 2007.

39. Dixon-Woods, M.; Agarwal, S.; Young, B.; Jones, D.; Sutton, A. Integrative Approaches to Qualitative and Quantitative Evidence; Health Development Agency: London, UK, 2004.

40. Robinson, T.P.; Thornton, P.K.; Franceschini, G.; Kruska, R.; Chiozza, F.; Notenbaert, A.M.; Cecchi, G.; Herrero, M.; Epprecht, M.; Fritz, S. Global Livestock Production Systems; FAO: Rome, Italy; ILRI: Nairobi, Kenya, 2011.

41. Gethings, O.J.; Rose, H.; Mitchell, S.; Van Dijk, J.; Morgan, E.R. Asynchrony in host and parasite phenology may decrease disease risk in livestock under climate warming: Nematodirus battus in lambs as a case study. Parasitology 2015, 142, 1306-1317. [CrossRef] [PubMed]

42. Van Dijk, J.S.; Sargison, N.D.; Kenyon, F.; Skuce, P.J. Climate change and infectious disease: Helminthological challenges to farmed ruminants in temperate regions. Animal 2010, 4, 377-392. [CrossRef] [PubMed]

43. Verschave, S.H.; Charlier, J.; Rose, H.; Claerebout, E.; Morgan, E.R. Cattle and nematodes under global change: Transmission models as an ally. Trends Parasitol. 2016, 32, 724-738. [CrossRef] [PubMed]

44. Ahmed, F.A.; Al-Amin, A.Q.; Alam, G.M.; Hassan, C.H. Climate change concern to cattle feed in Bangladesh. J. Anim. Vet. Adv. 2012, 11, 1946-1953. [CrossRef]

45. Craine, J.M.; Andrew, J.; Olson, K.C.; Tolleson, D. Climate change and cattle nutritional stress. Glob. Chang. Biol. 2010, 16, 2901-2911. [CrossRef]

46. Sautier, M.M.; Martin-Clouaire, R.; Faivre, R.; Duru, M. Assessing climatic exposure of grassland-based livestock systems with seasonal-scale indicators. Clim. Chang. 2013, 120, 341-355. [CrossRef]

47. Wheeler, T.R.; Reynolds, C. Predicting the risks from climate change to forage and crop production for animal feed. Anim. Front. 2013, 1, 36-41. [CrossRef]

48. Kates, R.W.; Travis, W.R.; Wilbanks, T.J. Transformational adaptation when incremental adaptations to climate change are insufficient. Proc. Natl. Acad. Sci. USA 2012, 109, 7156-7161. [CrossRef] [PubMed]

49. Punsalmaa, B.B.; Buyndalai, B.; Nyamsuren, B. Adaptation measures to climate change in the Mongolian livestock sector. In Climate Adaptation Futures; John Wiley \& Sons: Hoboken, NJ, USA, 2013; pp. 279-283. [CrossRef]

50. Wako, G.T.; Tadesse, M.; Angassa, A. Camel management as an adaptive strategy to climate change by pastoralists in Southern Ethiopia. Ecol. Process. 2017, 6. [CrossRef]

51. Mu, J.E.; Bruce, A.; Wein, A.M. Adaptation to climate change: Changes in farmland use and stocking rate in the U.S. Mitig. Adapt. Strateg. Glob. Chang. 2013, 18, 713-730. [CrossRef]

52. Maiti, S.J.; Jha, S.K.; Garai, S.; Nag, A.; Chakravarty, R.; Kadian, K.S.; Chandel, B.S.; Datta, K.K.; Upadhayay, R.C. Adapting to climate change: Traditional coping mechanism followed by the Brokpa pastoral nomads of Arunachal Pradesh, India. Indian J. Tradit. Knowl. 2014, 13, 752-761. 
53. Mirza, M.M. Climate change and extreme weather events: Can developing countries adapt? Clim. Policy 2003, 3, 233-248. [CrossRef]

54. Derner, J.B.; Briske, D.; Reeves, M.; Brown-Brandl, T.; Meehan, M.; Blumenthal, D.; Travis, W.; Augustine, D.; Wilmer, H.; Scasta, D.; et al. Vulnerability of grazing and confined livestock in the Northern Great Plains to projected mid- and late-twenty-first century climate. Clim. Chang. 2017, 1-14. [CrossRef]

55. McKeon, G.M.; Stone, G. S.; Syktus, J.I.; Carter, J.O.; Flood, N.R.; Ahrens, D.G.; Bruget, D.N.; Chilcott, C.R.; Cobon, D.H.; Cowley, R.A.; et al. Climate change impacts on Northern Australian rangeland livestock carrying capacity: A review of issues. Rangel. J. 2009, 31, 1-29. [CrossRef]

56. Ghahramani, A.M.; Moore, A.D. Climate change and Broadacre livestock production across Southern Australia. 2. Adaptation options via grassland management. Crop Pasture Sci. 2013, 64, 615-630. [CrossRef]

57. Forman, S.; Hungerford, N.; Yamakawa, M.; Yanase, T.; Tsai, H.J.; Joo, Y.S.; Yang, D.K.; Nha, J.J. Climate change impacts and risks for animal health in Asia. Rev. Sci. Tech-Off. Int. Epizoot. 2008, 27, 581-597. [CrossRef]

58. Özkan, Ş.; Vitali, A.; Lacetera, N.; Amon, B.; Bannink, A.; Bartley, D.J.; Blanco-Penedo, I.; de Haas, Y.; Dufrasne, I.; Elliott, J.; et al. Challenges and priorities for modelling livestock health and pathogens in the context of climate change. Environ. Res. 2016, 151, 130-144. [CrossRef] [PubMed]

59. Gilbert, M.; Slingenbergh, J.; Xiao, X. Climate change and avian influenza. OIE Rev. Sci. Tech. 2008, 27, 459-466. [CrossRef]

60. West, J.W. Effects of heat-stress on production in dairy cattle. J. Dairy Sci. 2003, 86, 2131-2144. [CrossRef]

61. Skuce, P.J.M.; Morgan, E.R.; van Dijk, J.; Mitchell, M. Animal health aspects of adaptation to climate change: Beating the heat and parasites in a warming Europe. Anim. Int. J. Anim. Biosci. 2013, 7, 333-345. [CrossRef] [PubMed]

62. Oyekale, A.S. Impacts of climate change on livestock husbandry and adaptation options in the arid Sahel belt of West Africa: Evidence from a baseline survey. Asian J. Anim. Vet. Adv. 2014, 9, 13-26. [CrossRef]

63. Martin, R.; Muller, B.; Linstädter, A.; Frank, K. How much climate change can pastoral livelihoods tolerate? Modelling rangeland use and evaluating risk. Glob. Environ. Chang. 2014, 24, 183-192. [CrossRef]

64. Huho, J.M.N.; Ngaira, J.K.W. Pastoralism and the changing climate in the arid Northern Kenya. In Livestock: Rearing, Farming Practices and Diseases; Nova Science Publishers, Inc.: Hauppauge, NY, USA, 2011; pp. 1-16.

65. Kuczynski, T.; Blanes-Vidal, V.; Li, B.; Gates, R.S.; de Alencar Nääs, I.; Moura, D.J.; Berckmans, D.; Banhazi, T.M. Impact of global climate change on the health, welfare and productivity of intensively housed livestock. Int. J. Agric. Biol. Eng. 2011, 4.

66. Martinsohn, M.; Hansen, $\mathrm{H}$. The impact of climate change on the economics of dairy farming-A review and evaluation. German J. Agric. Econ. 2012, 61, 80-95.

67. Ai-Amin, A.Q.; Alam, G.M. The impacts of climate change on animal health and economy: A way forward for policy option. Asian J. Anim. Vet. Adv. 2011, 6, 1061-1068.

68. Hansen, P.J. Heat stress and climate change. In Comprehensive Biotechnology, 2nd ed.; Elsevier: Amsterdam, The Netherlands, 2011; Volume 4, pp. 477-485.

69. Liu, Z.; Ezernieks, V.; Wang, J.; Arachchillage, N.W.; Garner, J.B.; Wales, W.J.; Cocks, B.G.; Rochfort, S. Heat stress in dairy cattle alters lipid composition of milk. Sci. Rep. 2017, 7, 961. [CrossRef] [PubMed]

70. Kadzere, C.T.; Murphy, M.R.; Silanikove, N.; Maltz, E. Heat stress in lactating dairy cows: A review. Livest. Prod. Sci. 2002, 77, 59-91. [CrossRef]

71. Joshi, S.J.; Jasra, W.A.; Ismail, M.; Shrestha, R.M.; Yi, S.L.; Wu, N. Herders' perceptions of and responses to climate change in Northern Pakistan. Environ. Manag. 2013, 52, 639-648. [CrossRef] [PubMed]

72. Gaughan, J.; Cawdell-Smith, A.J. Impact of climate change on livestock production and reproduction. In Climate Change Impact on Livestock: Adaptation and Mitigation; Springer: New Delhi, Indian, 2015; pp. 51-60.

73. Hristov, A.N.; Degaetano, A.T.; Rotz, C.A.; Hoberg, E.; Skinner, R.H.; Felix, T.; Li, H.; Patterson, P.H.; Roth, G.; Hall, M.; et al. Climate change effects on livestock in the northeast us and strategies for adaptation. Clim. Chang. 2017, 1-13. [CrossRef]

74. Salama, A.A.; Caja, G.; Hamzaoui, S.; Badaoui, B.; Castro-Costa, A.; Façanha, D.A.E.; Guilhermino, M.M.; Bozzi, R. Different levels of response to heat stress in dairy goats. Small Rumin. Res. 2014, 121, 73-79. [CrossRef] 
75. Magrin, G.; Marengo, J.; Boulanger, J.; Buckeridge, M.; Castellanos, E.; Poveda, G. Central and South America in Climate Change 2014: Impacts, Adaptation, and Vulnerability, Part B: Regional Aspects; Contribution of Working Group II to the Fifth Assessment Report of the Intergovernmental Panel of Climate Change; Cambridge University Press: Cambridge, UK, 2014; pp. 1499-1566.

76. Hijioka, Y.; Lin, E.; Pereira, J.; Corlett, R.; Cui, X.; Insarov, G.; Lasco, R.; Lindgren, E.; Surjan, A. Climate Change 2014: Impacts, Adaptation, and Vulnerability, Part B: Regional Aspects; Contribution of Working Group II to the Fifth Assessment Report of the Intergovernmental Panel on Climate Change; Cambridge University Press: Cambridge, UK, 2014; pp. 1327-1370.

77. Nurse, L.A.; McLean, R.F.; Agard, J.; Briguglio, L.P.; Duvat-Magnan, V.; Pelesikoti, N.; Tompkins, E.; Webb, A. Small islands. In Climate Change 2014: Impacts, Adaptation and Vulnerability, Part B: Regional Aspects, Chapter 29 (Small Islands); Contribution of Working Group II to the Fifth Assessment Report of the Intergovernmental Panel on Climate Change; Cambridge University Press: Cambridge, UK, 2014; pp. 1613-1654.

78. Thamo, T.A.; Addai, D.; Pannell, D.J.; Robertson, M.J.; Thomas, D.T.; Young, J.M. Climate change impacts and farm-level adaptation: Economic analysis of a mixed cropping-livestock system. Agric. Syst. 2017, 150, 99-108. [CrossRef]

79. Reed, M.S.; Podesta, G.; Fazey, I.; Geeson, N.; Hessel, R.; Hubacek, K.; Letson, D.; Nainggolan, D.; Prell, C.; Rickenbach, M.G.; et al. Combining analytical frameworks to assess livelihood vulnerability to climate change and analyse adaptation options. Ecol. Econ. 2013, 94, 66-77. [CrossRef] [PubMed]

80. Reidsma, P.; Wolf, J.; Kanellopoulos, A.; Schaap, B.F.; Mandryk, M.; Verhagen, J.; van Ittersum, M.K. Climate change impact and adaptation research requires farming systems analysis and integrated assessment: A case study in the netherlands. Procedia Environ. Sci. 2015, 29, 286-287. [CrossRef]

81. Eriksen, S.H.; O’Brien, K. Vulnerability, poverty and the need for sustainable adaptation measures. Clim. Policy 2007, 7, 337-352. [CrossRef]

82. Thornton, P.K.; Herrero, M. Adapting to climate change in the mixed crop and livestock farming systems in Sub-Saharan Africa. Nat. Clim. Chang. 2015, 5, 830. [CrossRef]

83. Tarawali, S.; Herrero, M.; Descheemaeker, K.; Grings, E.; Blümmel, M. Pathways for sustainable development of mixed crop livestock systems: Taking a livestock and pro-poor approach. Livest. Sci. 2011, 139, 11-21. [CrossRef]

84. Halimani, T.E.; Muchadeyi, F.C.; Chimonyo, M.; Dzama, K. Opportunities for conservation and utilisation of local pig breeds in low-input production systems in Zimbabwe and South Africa. Trop. Anim. Health Prod. 2012, 45, 81-90. [CrossRef] [PubMed]

85. Kantanen, J.; Løvendahl, P.; Strandberg, E.; Eythorsdottir, E.; Li, M.-H.; Kettunen-Præbel, A.; Berg, P.; Meuwissen, T. Utilization of farm animal genetic resources in a changing agro-ecological environment in the Nordic countries. Front. Genet. 2015, 6, 52. [CrossRef] [PubMed]

86. Cox, M.G.; Gardner, W.C.; Fraser, L.H. A survey-based assessment of cattle producers' adaptation to climate change in British Columbia, Canada. Rangel. Ecol. Manag. 2015, 68, 119-130. [CrossRef]

87. Harrison, M.T.; Cullen, B.R.; Armstrong, D. Management options for dairy farms under climate change: Effects of intensification, adaptation and simplification on pastures, milk production and profitability. Agric. Syst. 2017, 155, 19-32. [CrossRef]

88. Chingala, G.M.; Mapiye, C.; Raffrenato, E.; Hoffman, L.; Dzama, K. Determinants of smallholder farmers' perceptions of impact of climate change on beef production in malawi. Clim. Chang. 2017, 142, 129-141. [CrossRef]

89. Adger, N.; Saleemul, H.; Katrina, B.; Declan, C.; Mike, H. Adaptation to climate change in the developing world. Prog. Dev. Stud. 2003, 3, 179-195. [CrossRef]

90. Morton, J.F. The impact of climate change on smallholder and subsistence agriculture. Proc. Natl. Acad. Sci. USA 2007, 104, 19680-19685. [CrossRef] [PubMed]

(C) 2018 by the authors. Licensee MDPI, Basel, Switzerland. This article is an open access article distributed under the terms and conditions of the Creative Commons Attribution (CC BY) license (http://creativecommons.org/licenses/by/4.0/). 